\title{
Is there a relationship between right-wing populism and radicalisation to Islamic extremism in the UK and, if so, what is the nature of this relationship?
}

\author{
Taryn Thompson ${ }^{1}$
}

\begin{abstract}
This paper examines the nature of the relationship between right-wing populism and radicalisation to Islamic extremism in the UK. Through the critical analysis of themes and commonalities within existing literature on both individual fields, it is shown that there exists a relationship between the two phenomena, though this relationship has many intricacies. This paper argues that right-wing populism, along with counter-terrorism policy and the media, construct an anti-Muslim narrative, which fosters discrimination and, ultimately, leads to the social exclusion of Muslim suspect communities, a known cause of radicalisation. This research further reveals that this relationship, while significant, is not causal, using cumulative extremism to explain its multidirectional nature. Drawing attention to the relationship between right-wing populism and radicalisation opens up a new approach to understanding the impact current UK politics and the media have on the issue of "homegrown" terrorism. This paper aims to promote engagement with the question of how, as a society, we can implement more effective and less discriminative counterterrorism policy, as well as become more aware of the impact of the media.
\end{abstract}

In recent years, it has become apparent that right-wing populism has transitioned from being an ideology of the radical-right to becoming integrated into Western mainstream politics (Akkerman, 2012). In 2016, both the Brexit referendum in the UK and the election of Donald Trump as American President, evidenced this shift. The Muslim community has frequently been a target of these campaigns and this cannot be without consequence. Trends in rightwing populism seemingly coincide with peaks of Islamic extremism in the West, yet this relationship has not been previously investigated.

The significance of Brexit, alongside a noticeable peak in domestic terrorism during 2017 (Ritchie et al, 2019), directs this research to focus on the UK. Furthermore, this paper will concentrate on radicalisation to Islamic extremism, excluding other forms of extremism, such as far-right. This is due to the extent of current anti-Muslim sentiment in rightwing populist discourse, as well as the opportunity to investigate a gap in research. It is extremely valuable to analyse the impacts of right-wing populism on radicalisation to Islamic extremism since increasing right-wing populism and domestic terrorism are pressing issues of current relevance. The formulation of new understandings on this topic can spark debate and provide the opportunity to suggest revisions to current policy in favour of a more effective approach.

An exploratory approach will be adopted as a relationship between right-wing populism and radicalisation has not been investigated previously, making it important to formulate cohesive and comprehensive conclusions (Neuman, 2014). To do so, this paper will systematically discuss and analyse right-wing populism and radicalisation to Islamic extremism by initially looking into the phenomena individually, so that patterns and themes 
Vol. 8, No. 1, 34-49.

connecting the two may be observed. Firstly, the definition of right-wing populism will be outlined, and its parallels to colonialism will be discussed in order to build an understanding of the postcolonial societal structures and identities facilitating and enabling right-wing populism. It will be argued, with specific reference to Trump's presidency and Brexit, that the extent of right-wing populism has increased in Western societies over the past years. Secondly, this paper will engage with debate on the definition and causes of radicalisation to Islamic extremism in the UK. This structure has been adopted to allow for a direct comparison between the extent and impact of right-wing populism and the causes of radicalisation to Islamic extremism. Significant themes and connections will be revealed and analysed to build a picture of the true relationship between the two phenomena. Going back to the definition of radicalisation, this paper will address how right-wing populist discourse can misappropriate the term, and explore what this means for the Muslim community. Furthermore, this paper will examine how counter-terrorism policy and the media, as two key observed themes, utilise this misappropriation and, in turn, disseminate right-wing populist discourse more broadly.

Having discussed the mechanisms by which right-wing populist discourse is dispersed, and investigated the impacts of this discourse in depth, this paper will conclude by debating the extent to which right-wing populism and radicalisation to Islamic extremism can be linked. Initially, this will involve connecting the impacts of right-wing populism to the causes of radicalisation to Islamic extremism to establish that a relationship exists. The nature of this relationship will then be judged through critical analysis of trends and theories of radicalisation to effectively answer the research question at hand. Lastly, recommendations for future research and revisions to policy will be suggested.

\section{Right-wing populism}

To understand right-wing populism, it is essential to first become familiarised with definitional work on the term. There is little variation in scholarly definitions of right-wing populism. Firstly, the narrative of populism is understood to be "the juxtaposition of a (corrupt) political class, elite, or establishment, and the people" (Greven, 2016: 1). It is agreed that right-wing populism is characterised through the addition of a "second antagonism of us versus them" (Greven, 2016: 1; Mudde, as cited in Muis and Immerzeel, 2017). The key ideology of right-wing populists and parties is the othering of minorities and an "own people first" slogan (Betz, 1994; Rydgren, 2005). Rydgren (2005) acknowledges three key features of new anti-immigrant parties in Western Europe, the first being an othering and contempt for immigrants. It is clear that the defining feature of right-wing populism is a framing of immigrants as the cause of pressing socio-economic issues (Greven, 2016; Betz, 1994; Rydgren, 2005). This ideology mimics that of our colonial past, which "involved forms of subjugation of one people by another" (Young, 2016: 15), where typically white Europeans were the colonisers (Loomba, 1998). Colonialism originated with a crusade against Islam, as Middle Eastern people were depicted as uncivilised and dangerous, and so colonisation was justified under the pretense of civilising missionary work (Said, 1977; Young, 2016). It is the belief that other populations were not capable of governing themselves, the idea that Muslims, in particular, were uncivilised and dangerous, that is ingrained within our postcolonial society and draws parallels to right-wing populist ideology today. For this reason, right-wing populism cannot be comprehended wholly without understanding that colonialism has shaped the structures and identities on which our modern society is based, facilitating right-wing populism and various other ideologies that are discriminative of minority groups. Young (2016: 11) rightly asserts the consideration of colonialism to be essential in providing context for the "oppression and coercive domination that operate in the contemporary world". 
Right-wing populism and radical-right populist parties have become considerably more influential in global politics during the last decades (Backes and Moreau, 2012; Siddiqui, 2018; Wodak, 2015). According to Backes and Moreau (2012), support for populist radicalright parties has amplified in recent times and right-wing populism has become widespread. Kaplan and Weinberg (1998) have observed the emergence of the Euro-American radicalright in the face of multiculturalism, immigration and worsening life opportunities, leading many to feel like strangers in their own country. Akkerman (2012) attributes the emergence of this Euro-American radical-right to increasing support for radical-right parties around the globe, forcing centre-right parties to reconsider their policies and turn to right-wing populism in order to compete for votes. This explains how right-wing populism has entered the mainstream political discourse and how the ideology has become widespread (ibid). Events, such as the election of former American President Donald Trump and Brexit, are evidence of growing right-wing populism (Beland, 2019; Winlow et al, 2016). These examples will now be explored to showcase the current extent of right-wing populism across Western societies.

\section{American context}

Islamophobia became a prominent political issue in 2009-10 with the "Birther" movement in America, supported by Donald Trump, attempting to discredit then President Barack Obama by accusing him of being a Muslim born in Kenya (Mondon and Winter, 2017). Trump then continued during his own presidency to vocalise anti-Muslim feeling. His implementation of what is known as the "Muslim ban" restricted access to the United States from Muslimmajority countries on the basis that individuals from these countries pose a terrorist threat to American citizens, with no further justification (Niayesh, 2019). As Trump's presidency continued, anti-Muslim sentiment increased, with $64 \%$ of candidates in the 2018 midterm elections openly targeting Muslims and allowing conspiracy theories focused on Muslims to enter mainstream politics (Siddiqui, 2018). Trump legitimised the radical-right in America and seeks to extend this to the UK through his endorsement of anti-Muslim videos originating from British far-right group, Britain First (Weaver et al, 2017). Actions taken and statements made by the former American President have often been shown to lack factual rationalisation, suggesting his goal was to exaggerate the threat posed by the Muslim community and Islamic extremism to rally Republican supporters (Baker, 2019). Current events have highlighted just how severe the ramifications of right-wing populist discourse can be, with Trump inciting an insurrection of the Capitol building in protest of losing a fair and democratic election (Borger, 2021). Hundreds of dedicated supporters were not only willing, but enthused, to carry out an attack on a landmark of American democracy, showcasing the extent to which Trump's right-wing and discriminative messages have become ingrained into so many American people (ibid). The former President has become the first to be impeached twice and the first to be impeached after the end of his term, which truly displays the gravity of these events and how damaging right-wing populism can be to multicultural and democratic societies (Gambino, 2021). Now, while these events have taken place in the United States, globalisation and the internet allow the ideology to be dispersed globally, which is why it is so relevant to assess the extent of right-wing populism around the globe and not solely focus on the United Kingdom.

\section{British context}

The Brexit referendum in 2016 has generated intense debates over many issues associated with remaining in the EU; one of huge concern to many is immigration (Gough, 2017). Leave voters and campaigners, for example the UK Independence Party (hereafter UKIP), focused 
Vol. 8, No. 1, 34-49.

on right-wing populist ideologies to scapegoat immigrants, including Muslims, and panic the British public into voting leave (Stewart and Mason, 2016). The referendum divided Britain, resulting in widespread discrimination against Muslims who have increasingly become victim to hate crimes (Home Office, 2019). A Home Office (2019) report shows sizable spikes in hate crime in relation to both the EU referendum and the terrorist attacks in 2017. More recently, the government's prolonged efforts to achieve a Brexit deal brought about an early general election in December 2019, which saw parties focus heavily on the Brexit issue. An article written by The Economist (2019) draws on opinion surveys to demonstrate the speed at which the UK Brexit Party gained support after splitting off from UKIP. "The latest survey gives populist parties a combined vote of $21 \%$ ”, which is significant considering at the same time the Conservatives polled at $14 \%$ (ibid). This is evidence to suggest the anti-immigrant campaigns are successfully dispersing right-wing populist ideas across the UK at speed. The general election also saw the Conservative party accused of having a major problem with Islamophobia, which the party have promised to address (Murphy, 2019). But Prime Minister Boris Johnson has, himself, made Islamophobic comments against Muslims by likening Muslim women wearing burkas to letterboxes (ibid). Jenkins (2019) believes this general election was much more about identity than money, with the Conservatives polling higher than Labour throughout, despite Labour's promise to put more money into valued services. The explanation suggested for this is that the majority of UK voters are voting to save what they perceive as their British identity, which the Islamophobic, anti-immigrant messages the Conservative party presented during this campaign promised to deliver (ibid). It is evident that right-wing populism, and subsequently anti-immigrant and anti-Muslim views, have increased in extent across Western societies in recent times (Backes and Moreau, 2012).

\section{Radicalisation}

"At the most basic level, radicalization can be defined as the process whereby people become extremists" (Neumann, 2013: 874). However, there is much disagreement over the intricacies and use of this term. While it is widely agreed that radicalisation is a process, it is not agreed upon whether the end result of this process is purely cognitive, being the adoption of radical ideas, or if radical behaviours resulting from these ideas must be exhibited (Neumann, 2013). Additionally, Hoskins and O'Loughlin (2009: 109) observe "there is no generalizable set of characteristics, single demographic profile, or typical pathway to violent extremism", adding to the ambiguity of the term and creating challenges for application to policy and practitioners. This "fuzziness . . . allows everybody to conceive of radicalization as they like" (Crone, 2016: 587), creating the opportunity for the term to be misappropriated by different institutions and people. This is often exploited by politicians and the media.

\section{Causes of radicalisation}

Radicalisation is a relatively new explanation of how people come to be extremists. The evil nature of terror attacks has led to a widespread misconception that individuals involved must be mentally ill or "evil" (Reeves, as cited in Silke, 2019). This understanding very much adheres to Western depictions of the uncivilised, dangerous Middle East and religion of Islam, according to the theory of Orientalism (Said, 1977). Pearce (1977) argues that due to the evil nature of terrorism it is a sensible conclusion to label them as psychopaths. However, research has consistently failed to prove any significant link between mental health disorders, specifically psychopathy, and violent extremism (ibid; Crenshaw, 2011; Silke, 2019). Reeves (as cited in Silke, 2019) explains that psychopaths kill to satisfy their own personal desires and work individually, whereas terrorists are part of extensive, tight-knit groups, often killing to "avenge or inhibit" the suffering of their community (Reeves, as cited in Silke, 2019: 126). Moreover, 
Crenshaw (2011: 44) argues that "the outstanding common characteristic of terrorists is their normality" and lack of biological or psychological abnormalities. Counter-terrorism policy and the media often portray the cause of terrorism to be an "evil" Islamic ideology despite this contradictory research.

Research has persisted on other potential causes of terrorism. After the $9 / 11$ attacks in 2001, Islamic terrorism was very much "perceived of as an external threat to be handled through foreign intervention and draconian visa regimes that would prevent dangerous foreigners entering ... western countries" (Crone, 2016: 589). The narrative was very much that Islamic extremists all originated from war-torn countries in the Middle East and were propelled into terrorist organisations by a strong hatred of the West, desire for vengeance, and anti-imperialism (Crenshaw, 2011; Pargeter, 2008; Law, 2016). Historically, when looking at incidences of international terrorism, vengeance is a key characteristic (Crenshaw, 2011). Yet the revelation that the perpetrators of the $7 / 7$ London bombings were all British-born individuals, triggered understandings of the causes of terrorism to alter once again (Phillips, 2007). The process of radicalisation has now become central to explaining why one turns to terrorism, as vengeance resulting from experiences of international conflict cannot explain this newer trend of "homegrown" terrorism (Crenshaw, 2011).

Following the string of high-profile terror attacks since the start of the 21st century, anti-Muslim prejudice has been reinforced and Muslims are now the most at-risk community of being victim to discrimination and racism (Choudhury, 2005). Choudhury (2005) does not directly link this to radicalisation. However, the majority of existing literature on radicalisation argues that social exclusion and experiences of injustice within a discriminatory society are significant root causes of this phenomenon of "homegrown" extremism (Campelo et al, 2018; Crenshaw, 2011; Crone, 2016; Pargeter, 2008; Silke, 2019). Discrimination within politics and the media lead to the social exclusion and marginalisation of Muslims in society (Crenshaw, 2011). An entire community of people feel unsafe and resentful of being British because they are not included within the British national identity - in fact, the right-wing populist discourse is that they threaten this identity (Silke, 2019). The othering of minorities in this way is deeply rooted in our society as political, economic and social structures are still comprehended with a colonial mindset. Choudhury and Fenwick (2011: 151-152) articulate that "studies show that Al Qa'ida ... use discrimination and the social and political marginalisation of Muslims as part of their narrative for recruiting people to violence", showcasing the importance of understanding these factors as causes of radicalisation. Campelo et al (2018) agree that social exclusion and perceived injustice are major contributing factors to radicalisation for this reason, but have additionally created a three-step model outlining various other causes of the radicalisation of European youths. The individual factors of perceived injustice and mental state, the micro-environmental influences of friends, family and socialisation, and the macro-environmental influences of societal polarisation and geopolitics are all noted (ibid). This model is inclusive of many important contributing factors, but it can be said that many of these other factors, including socialisation through family and friends and mental state are influenced and inflamed by overarching social exclusion and discrimination. Therefore, discrimination, perceived injustice and social exclusion are arguably the predominant factors causing radicalisation to Islamic extremism and "homegrown" terrorism.

Reviewing right-wing populism and radicalisation to Islamic extremism separately has revealed key associations between the two. However, before debate begins on the nature of this relationship, it is important to understand the mechanisms by which such a relationship is fostered. Therefore, this paper will now argue that the defining of radicalisation within right-wing populist discourse is a key mechanism by which right-wing populism fuels feelings of social exclusion and perceived injustice in Muslim individuals and communities. These are two factors identified as being prominent causes of radicalisation to Islamic extremism. 
Vol. 8, No. 1, 34-49.

\section{Definitional misappropriation}

Various ambiguities of the definition of radicalisation have been previously outlined, including difficulties in agreeing upon the end result of radicalisation, as well as which communities are involved (Crone, 2016; Neumann, 2013). It is important to now discuss the impact of these ambiguities. Crone (2016: 587) explains that the "fuzziness" of the definition "allows everybody to conceive of radicalization as they like", which inevitably leads to misappropriation of the term. This has increasingly been the case within right-wing populist politics and the media. Many scholars have recognised the defining discourse of right-wing populism to be the framing of immigrants as the overwhelming cause of pressing socio-economic issues, including terrorism (Greven, 2016; Betz, 1994; Rydgren, 2005). A failing multicultural society is blamed for radicalisation and terrorism by right-wing populists, which very much plays to their nationalist agenda (Ragazzi, 2016). This rhetoric does not account for the farright terrorism that is sparked through the dissemination of right-wing populist ideology, as has been observed recently to be responsible for the insurrection of the Capitol building in the United States (Borger, 2021). Muslim communities are recurrently portrayed to be both the radicalisers and those vulnerable to radicalisation, subsequently fuelling their othering by painting them as a threat of which the public must be cognisant (Hoskins and O'Loughlin, 2009; Lazaridis, 2016). This securitisation of Muslims as a threat is ongoing, despite research showing that the most common feature uniting terrorists and extremists is not their race, ethnicity or faith, but their non-conformity to any one of these groups (ibid; Crenshaw, 2011). Current political and media discourse is therefore blinkered and extremely misleading. This discourse results in major consequences for the Muslim community, including social exclusion from "British" society and, subsequently, increased vulnerability to hate crime (Home Office, 2019), both known causes of radicalisation (Campelo et al, 2018). Together, counter-terrorism policy and the media are two key areas that have been identified that misappropriate the definition of radicalisation, disseminating and further securitising right-wing populist ideology to wider society.

\section{Counter-terrorism policy}

Scholarly work on the impact of counterterrorism policy on Muslim communities articulates that "state practices have a direct influence on how Muslims both perceive themselves and are perceived by the rest of society" (Ragazzi, 2016: 725). Anxieties have been raised that Muslims are being increasingly alienated by the implementation of counter-terrorism laws and policies. There are major concerns that counter-terrorism measures in the UK are feeding and sustaining Islamic extremism rather than preventing it (Choudhury and Fenwick, 2011). Aimed at tackling radicalisation, the Counterterrorism and Security Act 2015 (cited in McGovern, 2017), as well as Prevent Strategy (HM Government, 2011), enforce institutions to practise the prevention of terrorism by being watchful of individuals' behaviour. Originally, this was deployed countrywide to local authorities on the basis of percentage Muslim population, which many believe showcases the government's "pure and simple stigmatisation of the Muslim community" (Ragazzi, 2016: 728). Stop and search powers given to police under the Terrorism Act 2000, disproportionately focused on Muslims, only adds to this perception (Choudhury and Fenwick, 2011). These policies encourage suspicion of the Muslim community, creating feelings of social exclusion. Moreover, the reluctance to place equal focus on the "major threat" of right-wing terrorism to the UK (Sengupta, 2020) indicates that the "othering" of Muslims, embedded in postcolonial societies, is informing counter-terrorism policy, as opposed to common sense, evidence and reason.

However, it is interesting to note that not all Muslims have felt targeted by the state in this way, due to the diverse nature of Muslim communities and how the state chooses to 
operate its power. Ragazzi (2016) notes that the state observes two types of people: the "governable" who are trusted to abide by the rules of society, and the "ungovernable" who are not. The state makes the "governable" spokespeople for the Muslim community, for example the Mayor of London, Sadiq Khan, yet isolates and excludes those deemed "ungovernable" (ibid). These forced identities entrenched within our modern society stem from Orientalism (Said, 1977), whereby people from the Orient have been depicted as the uncivilised, dangerous "other". Colonial domination and control over the Orient were justified under the guise of a civilising and missionary purpose (Young, 2016). The present control over the Muslim community is an extension of colonialism through soft power and cultural imperialism, whereby traditional British culture and values, upheld by societal institutions, dominate those of minorities (Tomlinson, 2001). This social exclusion is achieved through framing the "evil" Islamic ideology as a threat to the UK and creating a suspect community of Muslims within which only the minority of "governable" individuals are excluded (Crone, 2016). Focus on Islamic extremist ideology as a cause of terrorism is ineffective in tackling the issue because the root cause is not being addressed (ibid). Moreover, social exclusion of the Muslim community can exacerbate radicalisation rather than reduce it, so currently implemented counter-terrorism policy is counterproductive (Hargreaves, 2018; Awan, 2012). Academics (ibid) agree this current top-down approach to counter-terrorism is aggravating the issue of radicalisation, recommending instead a community-based approach aiming to overcome feelings of exclusion within suspect communities.

\section{The British media}

It is not only counter-terrorism policy that constructs suspect communities - the media also plays a huge role. The 21st century has been defined as the "yellow journalism era", during which changing political context has resulted in "a media that is increasingly and to a dangerous degree driven by impact" (Udeze and Uzuegbunam, 2013: 70). Sensationalism is synonymous with tabloid newspapers where competition for sales and profits is prioritised over political impartiality (Udeze and Uzuegbunam, 2013). Therefore, it is no surprise that the anti-immigrant, anti-Muslim ideologies of right-wing populism, which are characteristic of recent political discourse, have been reflected in sensationalised articles on terrorism and radicalisation. The same discriminative view of radicalisation utilised by current UK counterterrorism policy, that "evil" Islamic ideology is the threat, is adopted by the media (Crone, 2016). This is a major problem due to what Hjarvard (2008) terms as the mediatisation of society. Mediatisation occurs when "society to an increasing degree is submitted to, or becomes dependent on, the media and their logic" (Hjarvard, 2008: 113; Awan et al, 2011). This blind dependence is harmful when the media abuses its power by delivering politicised, sensationalised news, often widely trusted and internalised. The general public are not made aware of societal issues that may cause terrorism, including the discrimination, hate crime and social exclusion these politicised, sensationalised articles promote.

The British tabloid media has consistently supported politicians and parties implementing right-wing populist ideologies in recent years. A media language analysis conducted by Loughborough University has exposed a strong newspaper bias favouring the Conservatives, with a score of +4 , which showcases positive portrayal, while Labour scored -91, displaying disproportionately negative coverage (Stone, 2019). In addition to this fact, the "positive coverage of the Conservatives came from the highest circulation newspapers" (Stone, 2019; Freedman and Cameron, 2019). And, therefore, articles politicised towards right-wing populism receive a much wider audience. Furthermore, Ofcom (2019) has found news is being more frequently consumed through social media, which has turned attention to news platforms such as Facebook. Vice president of communications, Nick Clegg, has stated that Facebook will allow politicians to post content that breaks rules on hate speech as long as there is no significant 
Vol. 8, No. 1, 34-49.

risk of harm (BBC News, 2019). This allows for a discriminatory discourse to be consumed and securitised countrywide by the general public, as has been seen with recent Islamophobia (Murphy, 2019). Beckett (2019) adds that far-right political figures, like Nigel Farage, having such persistent presence on television and social media sites, such as Twitter, further imposes right-wing populism and far-right ideology. Each example shows the media to actively support political parties advocating right-wing populism and discriminatory discourses across all media platforms. However, we have seen a break from this recently. Donald Trump has been banned from social media sites, including Twitter and Facebook, for his central role in inciting the insurrection of the Capitol building - an act of domestic terrorism (Waters and Murphy, 2021). It seems social media conglomerates are only willing to take far-right messages online seriously when extreme, violent and anti-democratic implications encouraged by the speech result. Even still, arguments of free speech and first amendment rights are already circling, defending Trump's right to disseminate his views online and offline, so it remains to be seen how long this ban will ensue and what the consequences may be (ibid).

The creation of politicised, sensationalised narratives of a Muslim suspect community are publicised by the media due to its impact-driven nature. The mediatisation of British society means this securitisation, along with that from counter-terrorism policy, is highly successful. In addition, online platforms based on the ideal of freedom of speech allow discriminative ideologies to be dispersed, with little regulation, to a wide audience (Gagliardone et al, 2015). These messages are internalised, which can explain spikes in discrimination and hate crime inevitably leading to increased discrimination and social exclusion. Hoskins and O'Loughlin (2009) support this view, arguing this media discourse to be increasingly alienating of Muslim communities and subsequently preventing commitment to uncover the root causes of terrorism and radicalisation.

\section{Causation debate}

The findings of this paper thus far, regarding the relationship between right-wing populism and radicalisation to Islamic extremism in the UK, will now be reviewed. It is essential to do so before engaging in a causation debate to assess the extent of this relationship. Right-wing populism, deriving from a colonial history of othering and controlling minorities, now drives centre-right parties, like the Conservatives, as a result of having to compete with radical-right parties and their growing popularity in recent years (Akkerman, 2012). This has had a huge impact on the reach of right-wing populism, as parties adopting this ideology are now in office with the opportunity to reflect the discourse in policy. This has been the case with counter-terrorism policy through the misappropriation of the definition of radicalisation to suit the political agenda. The adoption of right-wing populism into mainstream politics also created a Brexit leave campaign and a general election solely focused on immigration and the apparent issues of having a multicultural society. The media came into play hugely during this time by sensationalising these issues and very much backing the scapegoating of Muslim communities. This process explains recent spikes in religiously motivated hate crime, which inevitably leads to social exclusion and perceived injustice. Discrimination and social exclusion are reoccurring themes throughout this paper linking right-wing populism and radicalisation to Islamic extremism. There is no doubt that right-wing populism fuels nationalist ideologies, discrimination and anti-Muslim sentiment with the assistance of counter-terrorism policy and the media for securitisation (Greven, 2016; Betz, 1994; Rydgren, 2005). It is also apparent that social exclusion, perceived injustice and discrimination are key factors causing radicalisation to Islamic extremism (Campelo et al, 2018; Choudhury, 2005; Crone, 2016; Silke, 2019). With the impacts of right-wing populism aligning identically to significant causes of radicalisation, it can be suggested confidently that right-wing populism is a factor resulting in increased radicalisation to Islamic extremism. 
However, it is difficult to assess trends of radicalisation, which makes establishing a causal relationship with right-wing populism challenging, as direct correlations cannot be observed. Trends in radicalisation are hard to measure due to the ambiguities of the definition (Neumann, 2013). If the end result of radicalisation is terrorism, it can be measured through frequency of terrorist attacks alone. However, if the end result is an ideological change it cannot be measured accurately as it is impossible to know of every individual experiencing extremist thoughts. Moreover, academics assert there to be numerous causes of radicalisation, and so measuring one direct correlation is not possible due to multiple factors coinciding (Campelo et al, 2018).

Nevertheless, there are some ways patterns of radicalisation in the UK can be observed to assess whether there has been an increasing trend in line with right-wing populism. Regardless of the end result of radicalisation, it is inevitable that, as it increases, we are more likely to observe an increase in terrorist attacks. Sky News (McGuinness, 2017) has dubbed 2017 "Britain's year of terror". While the media is known to sensationalise terrorism with headlines such as this one (Udeze and Uzuegbunam, 2013), five major terrorist attacks took place in the UK during 2017, making it a peak year of domestic terrorism (Ritchie et al, 2019). This peak follows the Brexit referendum of June 2016, which we know was dominated by right-wing populist anti-Muslim ideology and coincides with drastic spikes in religiously motivated hate crime (Home Office, 2019). Through observing this trend, it can be argued that the right-wing populist ideologies disseminated throughout the Brexit campaigns sparked increases in hate crime, leading to the social exclusion of British Muslims and accounting for this noticeable peak in terrorism due to increased radicalisation. Additionally, youths becoming radicalised and travelling abroad to join terrorist organisations is another developing trend (Campelo et al, 2018). It can be argued that this measurable and growing movement is proof of an increasing trend in radicalisation of British individuals. Young women are particularly involved in this movement (ibid). This could be attributed to recent campaigns seen throughout Europe advocating for a ban on burkas, as well as Islamophobic comments directed at Muslim women, contributing to hate crime and their social exclusion (Jenkins, 2019). It seems though that many young Muslims involved in radicalisation of this type become involved online. Macdonald and Mair, 2015: 15 reasons that "the use of the internet for terrorist purposes is a rapidly growing phenomenon" with terrorist recruiters using a technique called "outreach" to radicalise youths online in particular. Hard to regulate online spaces are utilised to distribute terrorist propaganda and recruit vulnerable individuals (Gill et al., 2017; Macdonald and Mair, 2015). The growth of social media and online spaces in recent years must therefore be acknowledged as facilitating this trend and driving radicalisation. Even still, without right-wing populist messages resulting in anti-Muslim sentiment and social exclusion young Muslims would not be looking for somewhere to feel understood online, so this can still be asserted as a leading cause of radicalisation to Islamic extremism. Analysing this evidence, it can be argued that right-wing populism directs trends in radicalisation to Islamic extremism, establishing a relationship between the two despite lacking a direct measurable correlation.

While it appears clear that right-wing populism is directing trends in radicalisation, equally it could be argued that terrorism is simultaneously increasing support for right-wing populism. Travis (2017) notes a surge in religiously motivated hate crime following the 2017 peak of terror attacks, larger than the spike following the Brexit referendum. Terrorist attacks appear to confirm to the general public that the Muslim community and multiculturalism are a threat to Britain, securitising right-wing populist ideology. This impact is not surprising considering the shocking nature of terrorism (Freedman, 2007). Yet, media sensationalism of "evil" Muslim terrorists in the wake of attacks, alongside the refusal to address root causes of terrorism, perpetuates this ideology rather than seeking effective solutions (Hoskins and O'Loughlin, 2009). Irrespective of the mechanisms by which terrorism ends 
Vol. 8, No. 1, 34-49.

up breeding further right-wing populism, it does, meaning the relationship between rightwing populism and radicalisation to Islamic extremism cannot be explained as being straightforward or unilateral.

The term "cumulative extremism - namely, the way in which one form of extremism can feed off and magnify other forms" - was coined by Roger Eatwell (2006: 205). Carter (2020: 2) has more recently termed this "cumulative radicalisation". Islamic extremism is quite clearly a form of extremism, and right-wing populism, though now at home in mainstream politics, is an extreme right ideology, having been originally associated with radicalright groups such as the English Defence League and Britain First (Carter, 2020). In addition, right-wing domestic terrorism is unsurprisingly fuelled by right-wing populist rhetoric (Jones et al, 2020). A recent brief from the Centre for Strategic and International Studies (CSIS) reports an increasing trend of right-wing extremism in the United States alongside the right-wing populist discourse surrounding the latest Presidential election (ibid). It is clear that the ideology of right-wing populism ignites right-wing extremism Therefore, it must be argued that both right-wing populism and Islamic extremism are very much applicable to arguments of cumulative extremism and radicalisation.

This paper has established that right-wing populism furthers radicalisation to Islamic extremism, but Islamic extremism resulting from radicalisation also furthers right-wing populism, strongly suggesting a multidirectional relationship existing through the process of cumulative radicalisation. Feldman (2012: 1) explains that since the London terror attack of July 2007 "the emergence of a potent anti-Muslim politics has offered a crucial hook for a new generation of radical-right politicians to hang an extremist agenda - one palpable in some sections of the mainstream media and wider public". Feldman (2012) asserts these radical right politicians to be from groups such as the British National Party, though since this report the anti-Muslim, right-wing populist rhetoric of such groups have become aligned with mainstream, centre-right politics in both Britain and the United States. This means Feldman's explanation of how these groups foster the alienation of the Muslim community through radical-right discourse, leading to increased radicalisation to Islamic extremism, which in turn fuels further radical-right ideology, is applicable to current mainstream rightwing populism in Britain and across Western societies. Feldman (2012:1) also makes a notable link to the key involvement of the British media in fostering cumulative extremism, which this paper has previously explored to be a major driver of right-wing populist discourse. Looking at all the evidence, the relationship between current right-wing populism and radicalisation to Islamic extremism in the UK can be asserted as being one of cumulative radicalisation. Some academics strongly suggest cumulative extremism should be used to define extremist threats to the UK in order to implement more effective policy that can better understand and tackle this multidirectional relationship of extremist ideologies (Eatwell, 2006; Blakemore and Awan, 2013).

\section{Recommendations}

The conceptual nature of this paper means that themes and relationships can be observed and generalised to British society, which is extremely helpful for application to policy and promoting effective changes to combat the issues under research. Conceptual research is grounded in literature and nationwide trends, rather than subjective experience. Accordingly, a primary research study to capture individuals' personal experiences of right-wing populism and its impact on radicalisation to Islamic extremism would be a great way to add further understanding to this newly developing field of enquiry. Further research is advised to continue the development of an important research area, and to confirm the reliability and validity of arguments presented in this paper. 
With regards to application to policy, unfortunately, there is no quick fix or single recommendation to overcome the oppression of minorities in a society still deeply connected to a long history of colonialism, domination and othering. Yet, steps can be taken to move away from oppressive and discriminatory discourses within our institutions. The development of bottom-up counter-terrorism policy, in line with the recommendations of Hargreaves (2018) and Awan (2012), alongside the defining of extremist threats to the UK with cumulative extremism in mind (Eatwell, 2006; Blakemore and Awan, 2013) is strongly recommended. It is unrealistic to suggest restrictions be placed on the media and expression of political views considering arguments for freedom of speech. But, directing counterterrorism policy away from creating suspect communities and towards community building, as well as tackling cumulative extremism more effectively, is a realistic and necessary step in combating right-wing populist narratives and, consequently, radicalisation and "homegrown" terrorism.

\section{Conclusion}

This paper has opened a new field of enquiry into the nature of the relationship between right-wing populism and radicalisation to Islamic extremism in the UK. Due to a lack of existing literature, it was essential to initially examine the phenomena individually to allow for direct comparisons to be drawn between the impacts of right-wing populism and the causes of radicalisation to Islamic extremism. Through studying the definition of rightwing populism, it has been revealed that an anti-immigrant, discriminatory discourse lies at its core, with roots in colonialism and Orientalism (Said, 1977). Additionally, by looking into right-wing populism in both the United States and Britain over recent years, an increasing trend has been observed. Key themes and causes of radicalisation were then examined through analysis of definitional work. Social exclusion, discrimination and perceived injustice have each been uncovered as fundamental causes of radicalisation to Islamic extremism. While associations could be made between the two phenomena at this point, it was important to explore the mechanisms by which right-wing populism fostered the causes of radicalisation to Islamic extremism first. It has been argued that right-wing populist discourse misappropriates the definition of radicalisation to frame the Muslim community as being the main group involved in radicalisation, in doing so suggesting they pose a threat to British society. Both counter-terrorism policy and the media have been found to be disseminating and securitising this right-wing populist ideology to the general public. Counter-terrorism policies, such as Prevent Strategy (HM Government, 2011), were originally deployed and implemented to focus on the Muslim population, creating a suspect community. The media has sensationalised terrorism and radicalisation, and politicised news articles to strongly favour the Conservative right-wing populist narrative during Brexit and the 2019 general election campaign, securitising right-wing populism further. The impact of this discourse is the increased discrimination, hate crime and social exclusion of the Muslim community, all of which are predominant causes of radicalisation to Islamic extremism. Here, it has been established there exists a relationship, but its nature still needed to be critically analysed. Due to multiple possible causes of radicalisation and difficulty measuring trends, there is no single causal relationship whereby right-wing populism causes radicalisation. However, recent trends examined in this paper, including the radicalisation of youths and peaks in terror attacks, show right-wing populism to both direct and follow increases in radicalisation and homegrown terrorism. Therefore, it has been argued that cumulative radicalisation is propelling this multidirectional relationship as two extreme ideologies fuel one another. 
Vol. 8, No. 1, 34-49.

Consequently, this paper has recommended that extremist threats to the UK be defined through cumulative extremism, so the issue of domestic terrorism can be better prevented as its mechanisms are better understood (Eatwell, 2006). Additionally, the adoption of community-based counter-terrorism policy is advised to reduce suspicion placed on Muslim communities, lessen social exclusion and, subsequently, radicalisation (Hargreaves, 2018).

\section{Note}

${ }^{1}$ Taryn Thompson is a Criminology and Security Studies graduate of Birmingham City University. tarynt109@gmail.com

\section{References}

Akkerman, T. (2012) Comparing Radical Right Parties in Government: Immigration and Integration Policies in Nine Countries (1996-2010). West European Politics, 35(3). Available at: https://www.tandfonline.com/doi/full/10.1080/o1402382.2012.665738 [Accessed: 24 Oct 2019].

Awan, A., Hoskins, A. and O'Loughlin, B. (2011) Radicalisation and the Media: Connectivity and Terrorism in the New Media Ecology. Oxon: Routledge.

Awan, I. (2012) "I'm a Muslim Not an Extremist:" How Prevent Strategy Has Constructed a "Suspect" Community. Politics and Policy, 40(6), pp.1158-1185.

Backes, U. and Moreau, P., eds (2012) The Extreme Right in Europe: Current Trends and Perspectives. Göttingen: Vandenhoeck and Ruprecht.

Baker, P. (2019) "We the people": the battle to define populism. The Guardian, 1o January. Available at: https://www.theguardian.com/news/2019/jan/10/we-the-people-the-battle-todefine-populism [Accessed: 27 Nov 2019].

BBC News (2019) Facebook will not fact-check politicians. BBC News, 25 September. Available at: https://www.bbc.co.uk/news/technology-49827375 [Accessed: 10 March 2020].

Beckett, A. (2019) Britain was complacent about the far-right. Now it's out in force. The Guardian, 5 October. Available at: https://www.theguardian.com/commentisfree/2019/ oct/o5/britain-far-right-oswald-mosley-bbc-platform [Accessed: 19 Nov 2019].

Beland, D. (2019) Right-Wing Populism and the Politics of Insecurity: How President Trump Frames Migrants as Collective Threats. Political Studies Review, 18( 2), pp.162-177.

Betz, H. (1994) Radical Right-wing Populism in Western Europe. Hampshire: The Macmillan Press.

Blakemore, B. and Awan, I. (2013) Extremism, Counter-terrorism and Policing. [ebook] Surrey: Ashgate Publishing.

Borger, J. (2021) Insurrection Day: when white supremacist power came to the US Capitol. The Guardian, 9 January. Available at: https://www.theguardian.com/us-news/2021/jan/o9/ us-capitol-insurrection-white-supremacist-terror [Accessed: 18 Jan 2021].

Campelo, N., Oppetit, A., Neau, F., Cohen, D. and Bronsard, G. (2018) Who are the European youths willing to engage in radicalisation? A multidisciplinary review of their psychological and social profiles. European Psychiatry, 52, pp.1-14. 
Carter, A. (2020) Cumulative Extremism: A Comparative Historical Analysis. [ebook] Oxon: Routledge.

Choudhury, T. (2005) Muslims in the UK: Policies for Engaged Citizens. Budapest: Open Society Institute.

Choudhury, T. and Fenwick, H. (2011) The impact of counter-terrorism measures on the Muslim community. International Review of Law, Computers and Technology, 25(3), pp.151-181.

Crenshaw, M. (2011) Explaining Terrorism: Causes, processes and consequences. Oxon: Routledge.

Crone, M. (2016) Radicalisation revisited: violence, politics and the skills of the body. International Affairs, 92(3), pp.587-604.

Eatwell, R. (2006) Community Cohesion and Cumulative Extremism in Contemporary Britain. The Political Quarterly, 77(2).

Feldman, M. (2012) From Radical-Right Islamophobia to "Cumulative Extremism": A Paper on the Shifting Focus of Hatred [pdf]. London: Faith Matters. Available at: http://faith-matters. org/images/pdf/islamophobia.pdf [Accessed: 23 March 2020].

Freedman, D. and Cameron, D. (2019) Media bias is a gift to the Conservatives. The Guardian, 1 December. Available at: https://www.theguardian.com/media/2019/dec/o1/media-bias-isa-gift-to-the-conservatives [Accessed: 10 March 2020].

Freedman, L. (2007) Terrorism as a Strategy. Government and Opposition, 42(3), pp.314-339.

Gagliardone, I., Gal, D., Alves, T. and Martinez, G. (2015) Countering Online Hate Speech. [ebook]. Paris: United Nations Educational, Scientific and Cultural Organisation [UNESCO].

Gambino, L. (2021) Donald Trump impeached a second time over mob attack at US capitol. The Guardian, 13 January. Available at: https://www.theguardian.com/us-news/2021/jan/13/ trump-impeached-again-president-history-capitol-attack [Accessed: 18 Jan 2021].

Gill, P., Corner, E., Conway, M., Thornton, A., Bloom, M. and Horgan, J. (2017) Terrorist Use of the Internet by the Numbers: Quantifying Behaviours, Patterns and Processes. Criminology and Public Policy, 16(1), pp.99-117.

Gough, J. (2017) Brexit, xenophobia and left strategy now. Capital and Class, 41(2), pp.366-372.

Greven, T. (2016) The Rise of Right-wing Populism in Europe and the United States: A Comparative Perspective. Friedrich Ebert Stiftung. Available at: https://library.fes.de/pdffiles/id/12892.pdf [Accessed: 16 Oct 2019].

Hargreaves, J. (2018) Towards a Cure for Prevent? Building Resilience to Religious and Political Forms of Violence within British Muslim Communities. Journal of Muslims in Europe, 7: pp. 190-210. Available at: https://www.woolf.cam.ac.uk/assets/file-downloads/ Hargreaves-2018-Towards-a-cure-for-Prevent-JOME.pdf [Accessed: 26 Feb 2020].

Hjarvard, S. (2008) The Mediatization of Society: A Theory of the Media as Agents of Social and Cultural Change. Nordicom Review, 29: pp. 105-134.

HM Government (2011) Prevent Strategy. London: The Stationary Office.

Home Office (2019) Hate Crime, England and Wales, 2018/19. London: Home Office. 
Vol. 8, No. 1, 34-49.

Hoskins, A. and O'Loughlin, B. (2009) Media and the myth of radicalisation. Media, War and Conflict, 2(2): 107-110.

Jenkins, S. (2019) This election will be all about identity, not money. And the Tories know it. The Guardian, 28 November. Available at: https://www.theguardian.com/commentisfree/2019/nov/28/election-identity-money-tories-labour-public-spending [Accessed: 28 Nov 2019].

Jones, S. G., Doxsee, C. and Harrington, N. (2020) The Escalating Terrorism Problem in the United States. Washington D.C.: Centre for Strategic and International Studies [CSIS]. Available at: https://csis-website-prod.s3.amazonaws.com/s3fs-public/publication/200612_ Jones_DomesticTerrorism_v6.pdf [Accessed: 22 Jan 2021].

Kaplan, J. and Weinberg, L. (1998) The Emergence of a Euro-American Radical Right. London: Rutgers University Press.

Law, R. (2016) Terrorism: A History. 2nd end. Cambridge: Polity Press.

Lazaridis, G., ed. (2016) Security, Insecurity and Migration in Europe. [ebook] Oxon: Routledge.

Loomba, A. (1998) Colonialism/Postcolonialism. [ebook]. London: Routledge.

Macdonald, S. and Mair, D. (2015) Terrorism Online: A New Strategic Environment. In: Jarvis, L., Macdonald, S. and Chen, T. M, eds. Terrorism Online: Politics, Law and Technology. [ebook] Oxon: Routledge, pp. 10-34.

McGovern, M. (2017) The university, Prevent and cultures of compliance. Critical Studies in Innovation, 34(1): pp. 49-62.

McGuiness, A. (2017) Britain's year of terror: Timeline of attacks in 2017. Sky News, 15 September. Available at: https://news.sky.com/story/britains-year-of-terror-timeline-ofattacks-in-2017-11036824 [Accessed: 18 March 2020].

Mondon, A. and Winter, A. (2017) Articulations of Islamophobia: from the extreme to the mainstream? Ethnic and Racial Studies, 40(13): pp. 2151-2179.

Muis, J. and Immerzeel, T. (2017) Causes and consequences of the rise of populist radical right parties and movements in Europe. Current Sociology Review, 65(6): pp. 909-930.

Murphy, S. (2019) Sayeeda Warsi on Tory Islamophobia: "It feels like I'm in an abusive relationship". The Guardian, 27 November. Available at: https://www.theguardian.com/ politics/2019/nov/27/sayeeda-warsi-tory-islamophobia-muslim-prejudice-investigation [Accessed: 27 Nov 2019].

Niayesh, V. (2019) Trump's travel ban really was a Muslim ban, data suggests. The Washington Post, 26 September. Available at: https://www.washingtonpost.com/politics/2019/o9/26/trumps-muslim-ban-really-was-muslim-ban-thats-what-data-suggest/ [Accessed: 26 Nov 2019].

Neumann, P. (2013) The trouble with radicalization. International Affairs, 89(4), pp.873-893.

Neuman, W. L. (2014) Social Research Methods: Qualitative and Quantitative Approaches. 7th edn. [ebook] Essex: Pearson Education Limited.

Ofcom (2019) News Consumption in the UK: 2019. London: Jigsaw Research. Available at: https://www.ofcom.org.uk/_data/assets/pdf_file/oo27/157914/uk-news-consumption2019-report.pdf [Accessed: 5 Feb 2020]. 
Pargeter, A. (2008) The New Frontiers of Jihad: Radical Islam in Europe. London: I.B. Tauris.

Pearce, K. L. (1977) Police Negotiations: A new role for the community psychiatrist. Canadian Psychiatric Association Journal, 22(4), pp.171-175.

Phillips, M. (2007) Londonistan: How Britain is Creating a Terror State Within. London: Gibson Square.

Ragazzi, F. (2016) Suspect community or suspect category? The impact of counter-terrorism as "policed multiculturalism". Journal of Ethnic and Migration Studies, 42(5), pp.724-741.

Ritchie, H., Hasell, J., Appel, C. and Roser, M. (2019) Terrorism. [ebook] Available at: https:// ourworldindata.org/terrorism [Accessed: 18 March 2020].

Rydgren, J. (2005) Movements of Exclusion: Radical Right-wing Populism in the Western World. New York: Nova Science Publishers.

Said, E. (1977) Orientalism. [ebook] London: Penguin Group.

Sengupta, K. (2020) Violent right-wing extremism is a "major threat" in the UK, MI5 boss says. The Independent, 15 October. Available at: https://www.independent.co.uk/news/uk/ home-news/right-wing-extremism-terrorism-violence-uk-mi5-ken-mccallum-b1039501. html [Accessed: 18 Jan 2021].

Siddiqui, S. (2018) Anti-Muslim rhetoric "widespread" among candidates in Trump era - report. The Guardian, 22 October. Available at: https://www.theguardian.com/ us-news/2018/oct/22/anti-muslim-rhetoric-widespread-among-candidates-trump-era [Accessed: 26 Nov 2019].

Silke, A. (2019) Routledge Handbook of Terrorism and Counterterrorism. [ebook] Oxon: Routledge.

Stewart, H. and Mason, R. (2016) Nigel Farage's anti-migrant poster reported to police. The Guardian, 16 June. Available at: https://www.theguardian.com/politics/2016/jun/16/nigelfarage-defends-ukip-breaking-point-poster-queue-of-migrants [Accessed: 19 Nov 2019].

Stone, J. (2019) British newspapers heap positive coverage on Tories while trashing Labour, study finds. The Independent, 19 November. Available at: https:/www.independent.co.uk/ news/uk/politics/general-election-british-uk-media-news-bias-tories-labour-a9209026. html [Accessed: 10 March 2020].

The Economist (2019) Right-wing populist parties are polling well in Britain. The Economist, 15 April. Available at: https://www.economist.com/graphic-detail/2019/o4/15/right-wingpopulist-parties-are-polling-well-in-britain [Accessed: 19 Nov 2019].

Tomlinson, J. (2001) Cultural Imperialism: A Critical Introduction. 3rd edn. [ebook] London: Continuum.

Travis, A. (2017) Hate crime surged in England and Wales after terrorist attacks. The Guardian, 17 October. Available at: https://www.theguardian.com/uk-news/2017/oct/17/hate-soars-inengland-and-wales [Accessed: 18 March 2020].

Udeze, S. and Uzuegbunam, C. (2013) Sensationalism in the media: the right to sell or the right to tell? Journal of Communication and Media Research, 5(1), pp.69-78.

Waters, R. and Murphy, H. (2021) Donald Trump, Twitter, and the messy fight over free speech. Financial Times, 15 January. Available at: https://www.ft.com/content/78azed8cd930-4bf5-9f6e-1b6b475109of [Accessed: 18 Jan 2021]. 
Vol. 8, No. 1, 34-49.

Weaver, M., Booth, R. and Jacobs, B. (2017) Theresa May condemns Trump's retweets of UK far-right leader's anti-Muslim videos. The Guardian, 29 November. Available at: https:// www.theguardian.com/us-news/2017/nov/29/trump-account-retweets-anti-muslimvideos-of-british-far-right-leader [Accessed: 26 Nov 2019].

Winlow, S., Hall, S. and Treadwell, J. (2016) The Rise of the Right: English Nationalism and the Transformation of Working-Class Politics. [ebook] Bristol: Policy Press.

Wodak, R. (2015) The Politics of Fear: What Right-wing Populist Discourses Mean. [ebook] London: Sage Publications.

Young, R. J. C. (2016) Postcolonialism: An Historical Introduction. 2nd edn. [ebook] Sussex: John Wiley \& Sons. 